\title{
(c) \\ THREE-DIMENSIONAL VOLUMETRIC/LINEAR ANALYSIS AND AXIAL \\ CLASSIFICATION OF ROOT RESORPTIONS USING CONE BEAM COMPUTED TOMOGRAPHY: A RETROSPECTIVE STUDY
}

\begin{abstract}
Objectives: The purpose of this study was to investigate the volumetriclinear analysis and to present a new axial classification of root resorptions using cone beam computed tomography (CBCT).

Materials and Methods: A total of 43 teeth with root resorption (external cervical resorption $(\mathrm{ECR})(\mathrm{n}=27)$, external replacement resorption (ERR) $(n=4)$ and internal root resorption (IRR) $(n=12))$ from 34 patients were included in this study. On CBCT images of teeth, the volume of total tooth and resorption for the volumetric analysis, the widest lengths of resorptions and the amount of thinnest dentin thickness around them for the linear analysis were measured, and volumetric/linear measurements were compared according to age and gender. In addition, the eight regional axial classification was performed, and these regions were compared. Data were evaluated using Shapiro-Wilk, Pearson's r., Kruskal-Wallis and Dwass-SteelCritchlow-Fligner post-hoc tests. Significance was set at $\mathrm{p}=0.05$ for statistical analysis.
\end{abstract}

Results: No significant difference was found between the volumetric and linear measurements of ECRs, ERRs, and IRRs. No difference between genders in volumetric and linear measurements of ECRs and IRRs, except total tooth volume, was higher in males than in females in ECRs $(p<0.05)$. With increasing age in ECRs, the buccal dentin thickness increased, and bucco-lingual length and total tooth volume decreased $(\mathrm{p}<0.05)$. In axial classification, ECRs were mostly found in lingual, while IRRs and ERRs did not show regional differences.

Conclusions: Although root resorptions had different localizations and classifications, they did not differ in terms of volumetric and linear measurements due to having similar nature. Using CBCT imaging, the volumetric/linear analysis and axial classification of resorptions, and demographic differences according to these parameters can help clinicians in understanding the nature of resorption and in determining appropriate management.

Keywords: Classification, cone beam computed tomography, endodontics, root resorption.

\author{
*Tugba Kosar ${ }^{1}$ \\ Dilara Nil Gunacar ${ }^{2}$ \\ Taha Emre Kose ${ }^{2}$
}

ORCID IDs of the authors:

T.K. 0000-0001-5764-5510

D.N.G. 0000-0002-9607-6362

T.E.K. 0000-0003-3601-0393
Received : 05.03 .2021

Accepted : 02.05 .2021

How to Cite: Kosar T, Gunacar DN, Kose TE. Three-Dimensional Volumetric/Linear Analysis and Axial Classification of Root Resorptions Using Cone Beam Computed Tomography: A Retrospective Study. Cumhuriyet Dent J 2021;24:2:170-181.

*Corresponding Author:

Karadeniz Technical University, Faculty of Dentistry, Department of Endodontics, Trabzon, Turkey

Phone: +904623774735 E-mail: tugbakosar07@gmail.com 


\section{INTRODUCTION}

Root resorption (RR) is the loss of hard dental tissue as a result of clastic activities. ${ }^{1}$ RR can be classified in association to the surface of the root as internal or external. Internal root resorption (IRR) has been defined as intraradicular or apical with regard to location. ${ }^{2}$ External root resorption can be also subdivided into surface resorption (SR), external inflammatory resorption (EIR), external cervical resorption (ECR), external replacement resorption (ERR), and transient apical breakdown resorption (TAP). ${ }^{3}$

IRR especially occurs as a result of pulpal inflammation; however, external resorption types have different etiologies such as orthodontic treatment, cysts, trauma, etc. ${ }^{1,2}$ Oval or round in shape, IRR radiographically appears like a welldefined, ballooning out of the pulpal root canal. ${ }^{4}$ ECR that has a traceable root canal typically appears as an irregular radiolucency. In the reparative stage, the appearance of the lesion creates a mixed image due to the accumulation of calcific tissue. ${ }^{5}$

An accurate diagnosis is essential for establishing an appropriate treatment plan for root resorptions. ${ }^{4}$ Radiographic evaluation is a suitable method for the exact diagnosis. ${ }^{6}$ It is reported that $60-70 \%$ of mineralized tissue loss is required to determine resorption with conventional radiographs. $^{7}$ Periapical (PA) radiographs have limitations in comprehending the size and location, and in determining the relationship of the resorption area with surrounding tissues. ${ }^{89}$ Due to these limitations of PAs, cone beam computed tomography (CBCT) presents the threedimensional (3D) representations of hard tissues feature, the high-quality imaging, and the fast scanning. Moreover, CBCT provides an advantage in comprehensive and accurate evaluation of resorbed areas, as it ensures crosssectional assessment in sagittal, axial, coronal, and multiplanar planes. ${ }^{10}$

In 1999, Heithersay proposed four classes in PA radiography according to the extent of ECR. Resorption can range from class 1, a small cervical lesion with shallow penetration into dentin, to class 4 , a lesion extending beyond the coronal third of the root. ${ }^{11}$ This classification is valid if ECR is limited to the proximal aspect of the tooth. However, it also fails to describe the circumferential and pulpal involvement of the lesion and to predict treatment plans. ${ }^{12,13}$ In recent years, 3D classification of ECR has been proposed using CBCT by Patel et al. ${ }^{12}$ This new classification takes into account the ECR height, circumferential spread, and proximity to the root canal. ${ }^{12}$ Nevertheless, it does not give any information about the localization of resorptions in axial section.

CBCT has recently become popular in the measurement of remaining dentin thickness and the volume of resorptions. ${ }^{13,14}$ The increase in the 3D width and volume of the root resorption or the decrease in the thickness of the dentin around it can decrease the fracture resistance of tooth and the success of treatment. To the best of our knowledge, the study evaluating the 3D width and classifying the localization in axial section of root resorptions using CBCT could not be found in the literature search. Additionally, previous studies evaluating resorption using CBCT have generally investigated ECR lesions, not ERR, IRR. ${ }^{13,15}$ In $3 \mathrm{D}$ images, volumetric measurements such as the volume of resorption, and/or linear measurements (i.e. the widest length of resorptions, the thinnest dentin thickness around them) can help the physician to understand the nature and the differentiation of root resorption and to provide an advantage in the treatment decision.

Thus, this retrospective study had two aims. The first was to investigate the volume of ECRs, ERRs, IRRs, and total tooth, the widest length of these resorptions, and the amount of thinnest dentin thickness around them, and to compare the age and gender distribution according to these parameters. The secondary aim was to establish the eight regional settlement classifications in axial sections of CBCT and to compare the percentages in these regions of ECRs, ERRs, and IRRs.

\section{MATERIALS AND METHODS}

In this retrospective study, we evaluated patients' CBCT images with root resorption obtained between January 2017 and January 2020 in the 
Department of Oral and Maxillofacial Radiology, Recep Tayyip Erdoğan University, Faculty of Dentistry. This study was registered with www.clinicaltrials.gov/ (Identification number: NCT04617301) after approval (Number: 2020/98) by the Ethics Committee of the Recep Tayyip Erdoğan University Faculty of Medicine, and we followed the guidelines of the Helsinki Declaration in this investigation.

\section{Case Selection}

Cases of resorption, who had previously received CBCT for a definitive diagnosis and treatment plan, were included in the study. Patients who met the following criteria were excluded: those presenting pathologic lesions, congenital/ developmental anomalies or teeth with root canal filling, and those whose CBCT scans failed to present satisfactory quality. Additionally, SR, TAP, and EIR cases were excluded because their true dimensions could not be completely determined before resorption. Radiographic features of resorption were defined in the images of 34 patients in accordance with these criteria. A total of 43 teeth with ECR $(n=27)$, ERR $(n=4)$, and IRR ( $\mathrm{n}=12)$ were identified from 34 patients.

\section{Linear/Volumetric Analysis and Axial Classification}

The following parameters were registered: Gender, age, tooth number, and resorption type. For the linear measurements, the widest coronoapical length was made on sagittal sections where the tooth axis was perpendicular to the ground plane (Figure 1).

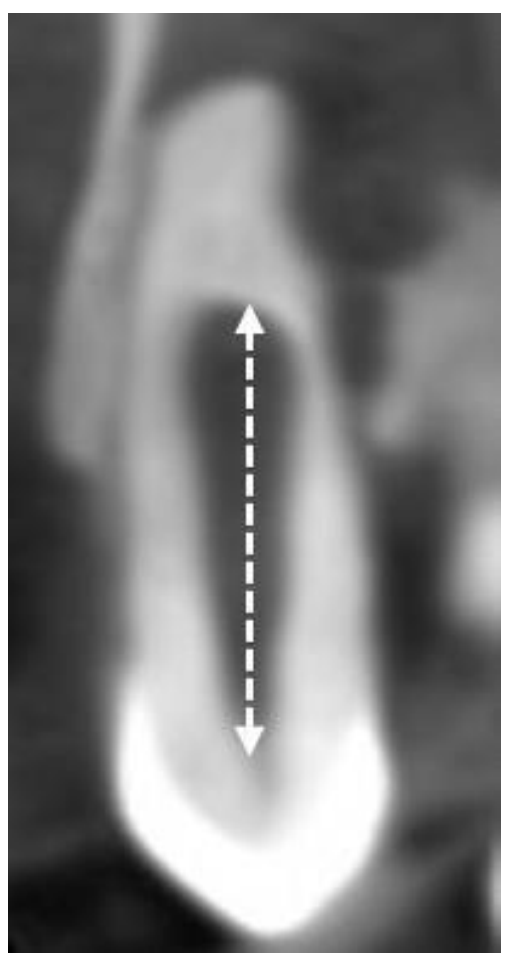

Figure 1. Linear measurement of the corono-apical length of the resorption area in sagittal slice of internal resorption case.

On axial sections, the width of the resorbed area (mesio-distal length and bucco-lingual length) (Figure 2A) and the thinnest dentin thickness (buccal, distal, mesial and lingual/palatinal) (Figure 2B) were measured.

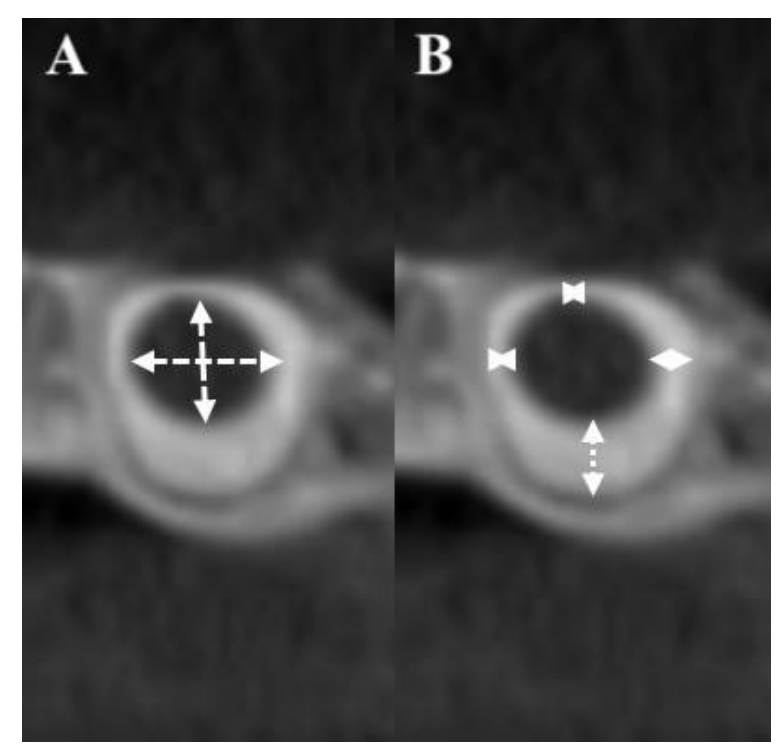

Figure 2. (A) Linear measurements of the mesio-distal and buccolingual width of resorption area, and (B) the thinnest dentin thickness around the resorption area in axial slice of internal resorption case.

For the volumetric assessment, volume calculations of total tooth and resorbed area were made with ITK-SNAP program (Figures $3 \mathrm{~A}$ and 3B). 


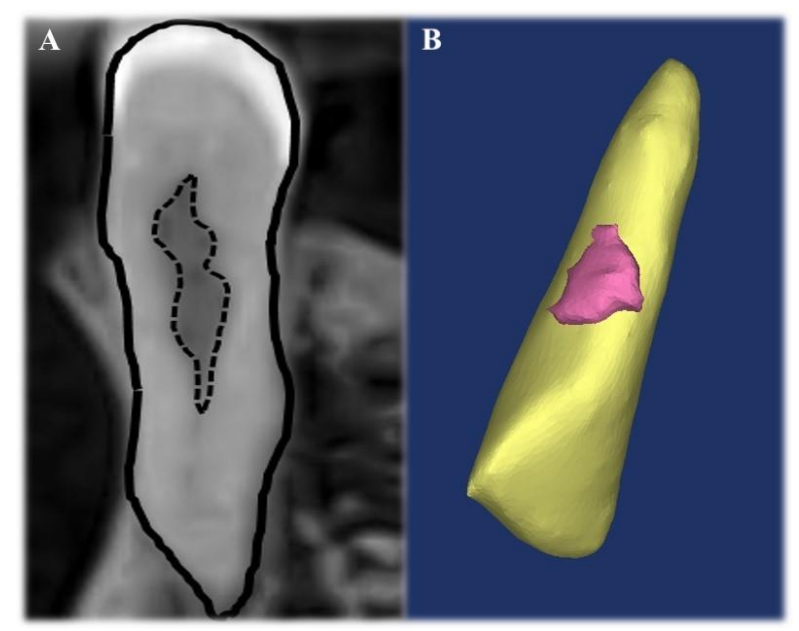

Figure 3. (A) Volumetric measurements of resorption and total tooth areas in a cross-sectional slice obtained from CBCT images of internal resorption case. (B) 3D reconstruction of resorption area and total tooth obtained during volumetric calculation with ITK-SNAP program in external cervical resorption case.

The apical reference point was the radiographic apex of the root and the coronal reference point was cusp tip(s) or incisal edge of tooth for the total volume. The total volume to resorption volume ratio was calculated after volumetric measurements. At the same time, the axial slice which showed the widest resorption area of the tooth was divided into eight parts and regional settlement classification was performed (Figure 4).

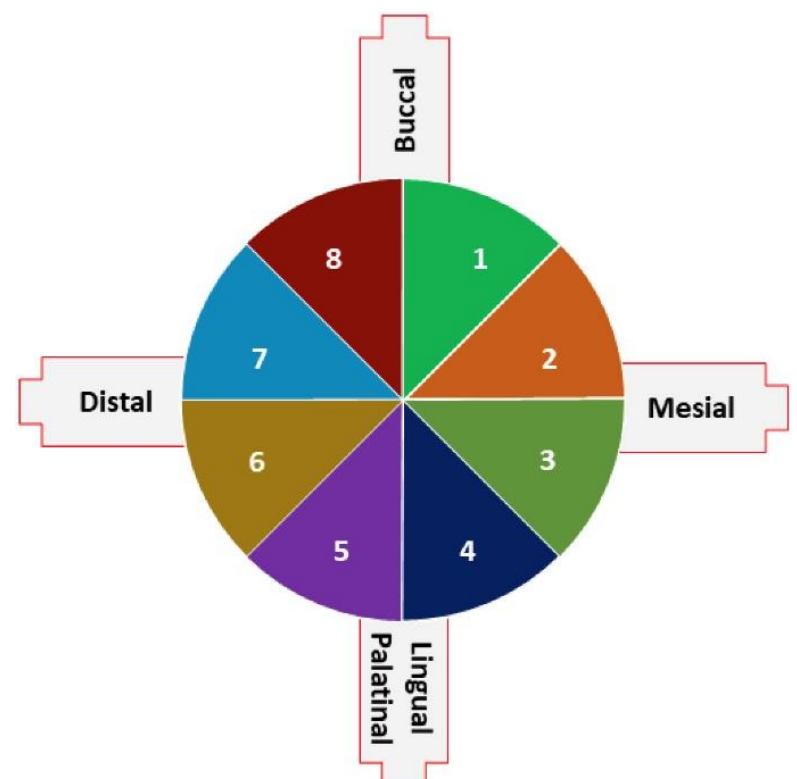

Figure 4. Eight regional settlement classification in the axial slice which showed the widest resorption area of the tooth in CBCT images.

\section{Height and Patel et al.'s ECR Classification}

In ERR or IRR, at sagittal and coronal slice, which showed the longest corono-apical extension, height classification was made according to the region (1: located in the crown, 2: in the coronal third of the root, 3: in the middle third of the root, 4: in the apical third of the root) (Figure 5).

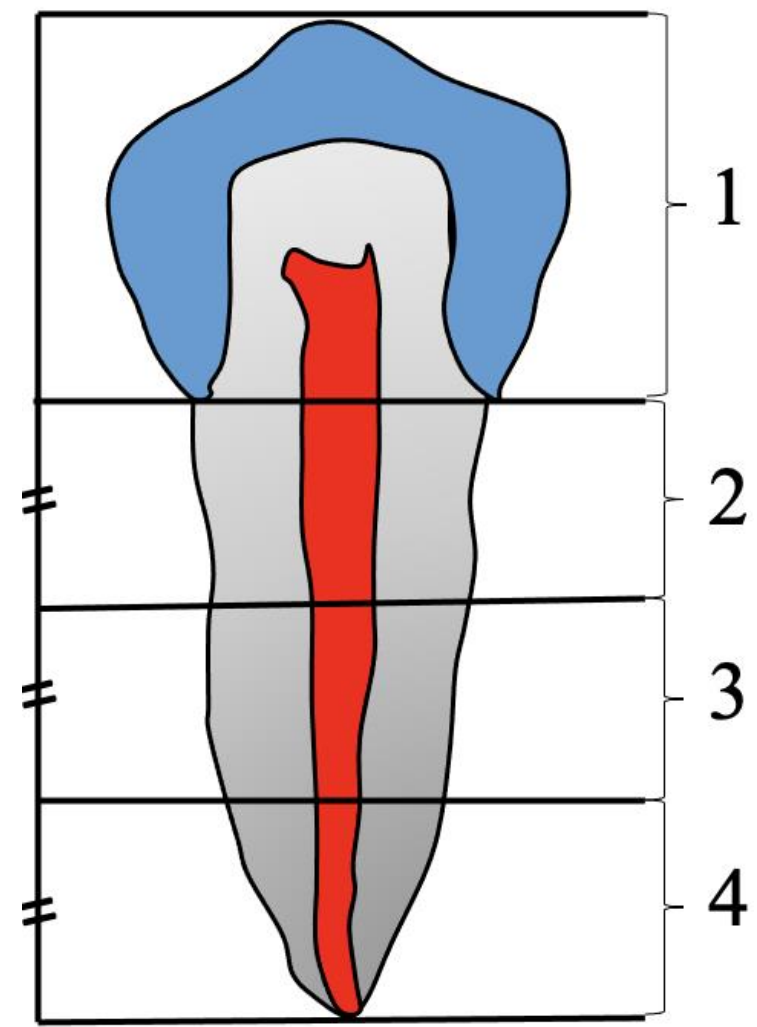

Figure 5. Height classification in sagittal and coronal slice which showed the longest corono-apical extension.

If the type of resorption was ECR, classification was performed based on Patel et al. 's ${ }^{12}$ study. In this classification, there are four subgroups for the height classification; cemento-enamel junction level or coronal to the bone crest (1: supracrestal), extension into the coronal third of the root and apical to the bone crest (2: subcrestal), extension into the middle third of the root (3), and extension into the apical third of the root (4). The classification of circumferential spread is made according to the area covered by the resorption (A: $\leq 90^{\circ}, \mathrm{B}:>90^{\circ}$ to $\leq 180^{\circ}, \mathrm{C}:>180^{\circ}$ to $\leq 270^{\circ}$, D: $>270^{\circ}$ ) in axial sections. The classification according to the proximity to the root canal in axial sections is made only if the lesion is limited to dentin or it contains probable pulp. ${ }^{12}$

\section{Radiographic Technique}

In every case, axial, coronal and sagittal slices with $0.2 \mathrm{~mm}$ interslice distance and $0.2 \mathrm{~mm}$ slice width were analyzed. All CBCT images were obtained using a Planmeca ProMax 3D Classic (Planmeca Promax 3D; Planmeca Oy; Helsinki, Finland) with the following parameters; $90 \mathrm{kVp}, 4-10 \mathrm{~mA}, 200$ $\mu \mathrm{m}$ voxel size. Linear measurements were 
performed using the Planmeca Romexis 4.6.2.R software (Planmeca Romexis; Helsinki, Finland). Volumetric calculations were made by creating a 3D image of the resorption areas and teeth into the 3D semi-automatic segmentation program (ITKSNAP 2.4), which was recorded as a DICOM data file obtained with CBCT. Linear measurements were made by an oral and maxillofacial radiologist (T.E.K.) with $10+$ years experience and volumetric measurements were made by the other oral and maxillofacial radiologist (D.N.G.) with 5+ years experience.

\section{Statistical Analysis}

In this study, frequencies, percentages, and descriptive statistics (e.g. mean, standard deviation) were used to report demographic information. Jamovi (Version 1.0.4) program was used for statistical analysis. The normality of data distribution was checked using the Shapiro-Wilk test. The correlation between groups was calculated by Pearson's r., Kruskal-Wallis and Dwass-Steel-Critchlow-Fligner post-hoc tests were used for statistical analysis for differences between groups. Significance was set at $\mathrm{p}=0.05$.

\section{RESULTS}

\section{Distribution}

A total of 43 teeth from 34 patients were evaluated in the study. The age range of these patients was 12-71 (range, 12-71 for ECR, 18-63 for IRR, 13-62 for ERR) years old, with an average of 41 (41.5 for ECR, 52.6 for IRR, 19.8 for ERR) years old. The records of 43 cases were identified, 26 of whom were male and 17 were female. Of the total 43 cases, 16 of 27 cases identified as having ECR were male and 11 were female; 9 of 12 cases identified as having IRR were male and 3 were female; and three of four cases identified as having ERR were female and one was male.

There were 27 cases of ECR in total with 14 identified in the maxilla, 10 of which were central incisors; 13 identified in mandibular, five of which were central incisors and five were first molars. There were 12 cases of IRR in total with eight identified in the maxilla, three of which were central incisors, two were laterals, and two were second molars. All four ERRs were in the maxilla, half of which were central, the remainder was lateral.

\section{Linear/Volumetric Analysis and Gender}

Table 1 presents the corono-apical/mesiodistal/bucco-lingual widest length, the thinnest buccal/mesial/distal/lingual/palatinal dentin thickness, the volume of ECR, ERR, IRR, the total volume of tooth and the total/resorption volume ratio. No significant difference was found between the values of these parameters $(p>0.05)$.

Table 1. Values for the widest lengths, the amount of thinnest dentin, and the volume according to ECR, ERR, and IRR.

\begin{tabular}{|c|c|c|c|c|c|c|c|c|c|c|c|}
\hline & $\begin{array}{l}\text { Resorption } \\
\text { type }\end{array}$ & $\begin{array}{c}\text { Corono- } \\
\text { apical } \\
\text { length } \\
(\mathbf{m m})\end{array}$ & $\begin{array}{c}\text { Mesio- } \\
\text { distal } \\
\text { length } \\
(\mathbf{m m})\end{array}$ & $\begin{array}{c}\text { Bucco- } \\
\text { lingual } \\
\text { length } \\
(\mathbf{m m})\end{array}$ & $\begin{array}{c}\text { Thinnest } \\
\text { buccal } \\
\text { dentin } \\
\text { (mm) }\end{array}$ & $\begin{array}{c}\text { Thinnest } \\
\text { mesial } \\
\text { dentin } \\
(\mathbf{m m})\end{array}$ & $\begin{array}{c}\text { Thinnest } \\
\text { distal } \\
\text { dentin } \\
(\mathbf{m m})\end{array}$ & $\begin{array}{c}\text { Thinnest } \\
\text { lingual/ } \\
\text { palatinal } \\
\text { dentin } \\
(\mathbf{m m})\end{array}$ & $\begin{array}{c}\text { Resorptio } \\
\text { n volume } \\
\left(\mathbf{m m}^{3}\right)\end{array}$ & $\begin{array}{c}\text { Total } \\
\text { tooth } \\
\text { volume } \\
\left(\mathrm{mm}^{3}\right)\end{array}$ & $\begin{array}{c}\text { Total } \\
\text { volume/ } \\
\text { resorptio } \\
\text { n volume } \\
\text { ratio } \\
\end{array}$ \\
\hline \multirow{3}{*}{$\begin{array}{l}\text { Mean } \\
( \pm \text { SD })\end{array}$} & $\begin{array}{c}\text { ECR } \\
(n=27)\end{array}$ & $\begin{array}{c}4.62 \\
( \pm 1.93)\end{array}$ & $\begin{array}{c}3.02 \\
( \pm 1.21)\end{array}$ & $\begin{array}{c}3.59 \\
( \pm 1.63)\end{array}$ & $\begin{array}{c}1.79 \\
( \pm 1.71)\end{array}$ & $\begin{array}{c}0.977 \\
( \pm 1.20)\end{array}$ & $\begin{array}{c}1.21 \\
( \pm 1.25)\end{array}$ & $\begin{array}{c}0.768 \\
( \pm 1.24)\end{array}$ & $\begin{array}{c}36.1 \\
( \pm 30.1)\end{array}$ & $\begin{array}{c}618 \\
( \pm 333)\end{array}$ & $\begin{array}{c}37.0 \\
( \pm 50.0)\end{array}$ \\
\hline & $\begin{array}{l}\text { ERR } \\
(\mathrm{n}=4)\end{array}$ & $\begin{array}{c}6.36 \\
( \pm 1.95)\end{array}$ & $\begin{array}{c}3.98 \\
( \pm 2.10)\end{array}$ & $\begin{array}{c}3.20 \\
( \pm 0.836)\end{array}$ & $\begin{array}{c}0.667 \\
( \pm 0.782)\end{array}$ & $\begin{array}{c}0.652 \\
( \pm 0.758)\end{array}$ & $\begin{array}{c}0.302 \\
( \pm 0.605)\end{array}$ & $\begin{array}{c}0.667 \\
( \pm 1.33)\end{array}$ & $\begin{array}{c}45.1 \\
( \pm 39.8)\end{array}$ & $\begin{array}{c}537 \\
( \pm 135)\end{array}$ & $\begin{array}{c}17.8 \\
( \pm 9.80)\end{array}$ \\
\hline & $\begin{array}{c}\text { IRR } \\
(n=12)\end{array}$ & $\begin{array}{c}5.08 \\
( \pm 3.19)\end{array}$ & $\begin{array}{c}2.38 \\
( \pm 0.901)\end{array}$ & $\begin{array}{c}3.31 \\
( \pm 1.34)\end{array}$ & $\begin{array}{c}1.53 \\
( \pm 1.93)\end{array}$ & $\begin{array}{c}0.597 \\
( \pm 0.399)\end{array}$ & $\begin{array}{c}0.676 \\
( \pm 0.786)\end{array}$ & $\begin{array}{c}1.23 \\
( \pm 0.889)\end{array}$ & $\begin{array}{c}29.2 \\
( \pm 21.2)\end{array}$ & $\begin{array}{c}624 \\
( \pm 269)\end{array}$ & $\begin{array}{c}49.8 \\
( \pm 60.5)\end{array}$ \\
\hline
\end{tabular}

Table 2 indicates the gender distribution of ECR, ERR, IRR, and total cases according to these parameters. There was no significant difference between the genders in these parameters for ECR, IRR, and total cases ( $>0.05)$, except the total tooth volume for ECR and total cases $(\mathrm{p}<0.05)$.
Total tooth volume was significantly higher in males than in females for ECR and total cases $(p<0.05)$. Due to the small sample size of ERR in the study, the differences between the genders according to these parameters could not be evaluated. 
Table 2. Values for the widest lengths, the amount of thinnest dentin, and the volume of ECR, ERR, IRR, and total cases according to gender.

\begin{tabular}{|c|c|c|c|c|c|c|c|c|c|c|c|c|}
\hline & Gender & $\begin{array}{l}\text { Resorption } \\
\text { type }\end{array}$ & $\begin{array}{l}\text { Corono- } \\
\text { apical } \\
\text { length } \\
(\mathbf{m m})\end{array}$ & $\begin{array}{l}\text { Mesio- } \\
\text { distal } \\
\text { length } \\
(\mathbf{m m})\end{array}$ & $\begin{array}{l}\text { Bucco- } \\
\text { lingual } \\
\text { length } \\
(\mathbf{m m})\end{array}$ & $\begin{array}{l}\text { Thinnest } \\
\text { buccal } \\
\text { dentin } \\
(\mathrm{mm})\end{array}$ & $\begin{array}{l}\text { Thinnest } \\
\text { mesial } \\
\text { dentin } \\
(\mathrm{mm})\end{array}$ & $\begin{array}{l}\text { Thinnest } \\
\text { distal } \\
\text { dentin } \\
(\mathbf{m m})\end{array}$ & $\begin{array}{l}\text { Thinnest } \\
\text { lingual/ } \\
\text { palatinal } \\
\text { dentin } \\
(\mathrm{mm})\end{array}$ & $\begin{array}{l}\text { Resorption } \\
\text { volume } \\
\left(\mathbf{m m}^{3}\right)\end{array}$ & $\begin{array}{l}\text { Total tooth } \\
\text { volume } \\
\left(\mathrm{mm}^{3}\right)\end{array}$ & $\begin{array}{l}\text { Total } \\
\text { volume/ } \\
\text { resorption } \\
\text { volume } \\
\text { ratio } \\
\end{array}$ \\
\hline \multirow{8}{*}{$\begin{array}{l}\text { Mean } \\
( \pm \text { SD })\end{array}$} & $\begin{array}{l}\text { Male } \\
(\mathrm{n}=26)\end{array}$ & $\begin{array}{l}\text { ECR } \\
(n=16)\end{array}$ & $\begin{array}{l}4.51 \\
( \pm 1.95)\end{array}$ & $\begin{array}{l}3.35 \\
( \pm 1.20)\end{array}$ & $\begin{array}{l}3.71 \\
( \pm 1.37)\end{array}$ & $\begin{array}{l}1.93 \\
( \pm 1.85)\end{array}$ & $\begin{array}{l}1.02 \\
( \pm 1.10)\end{array}$ & $\begin{array}{l}1.57 \\
( \pm 1.40)\end{array}$ & $\begin{array}{l}0.930 \\
( \pm 1.40)\end{array}$ & $\begin{array}{l}40.6 \\
( \pm 34.9)\end{array}$ & $\begin{array}{l}771 \\
( \pm 315)^{*}\end{array}$ & $\begin{array}{l}29.9 \\
( \pm 18.5)\end{array}$ \\
\hline & \multirow{7}{*}{$\begin{array}{l}\text { Female } \\
(\mathrm{n}=17)\end{array}$} & $\begin{array}{l}\text { ERR } \\
(n=1)\end{array}$ & 4.39 & 2.41 & 2.16 & 0.00 & 1.41 & 0.00 & 2.67 & 17.2 & 420 & 24.4 \\
\hline & & $\begin{array}{l}\text { IRR } \\
(\mathrm{n}=9)\end{array}$ & $\begin{array}{l}5.89 \\
( \pm 3.15)\end{array}$ & $\begin{array}{l}2.38 \\
( \pm 0.964)\end{array}$ & $\begin{array}{l}3.16 \\
( \pm 1.33)\end{array}$ & $\begin{array}{l}1.72 \\
( \pm 2.18)\end{array}$ & $\begin{array}{l}0.684 \\
( \pm 0.318)\end{array}$ & $\begin{array}{l}0.834 \\
( \pm 0.840)\end{array}$ & $\begin{array}{l}1.19 \\
( \pm 0.956)\end{array}$ & $\begin{array}{l}33.1 \\
( \pm 22.1)\end{array}$ & $\begin{array}{l}603 \\
( \pm 201)\end{array}$ & $\begin{array}{l}34.0 \\
( \pm 39.3)\end{array}$ \\
\hline & & $\begin{array}{l}\text { All } \\
\text { male } \\
\text { cases }(n=26)\end{array}$ & $\begin{array}{l}4.98 \\
( \pm 2.43)\end{array}$ & $\begin{array}{l}2.98 \\
( \pm 1.18)\end{array}$ & $\begin{array}{l}3.46 \\
( \pm 1.35)\end{array}$ & $\begin{array}{l}1.78 \\
( \pm 1.93)\end{array}$ & $\begin{array}{l}0.92 \\
( \pm 0.89)\end{array}$ & $\begin{array}{l}1.25 \\
( \pm 1.26)\end{array}$ & $\begin{array}{l}1.09 \\
( \pm 1.26)\end{array}$ & $\begin{array}{l}37.09 \\
( \pm 30.29)\end{array}$ & $\begin{array}{l}\text { 699.41 } \\
( \pm 286.81)^{* * *}\end{array}$ & $\begin{array}{l}31.13 \\
( \pm 26.58)\end{array}$ \\
\hline & & $\begin{array}{l}\text { ECR } \\
(n=11)\end{array}$ & $\begin{array}{l}4.78 \\
( \pm 1.99)\end{array}$ & $\begin{array}{l}2.54 \\
( \pm 1.10)\end{array}$ & $\begin{array}{l}3.42 \\
( \pm 2.01)\end{array}$ & $\begin{array}{l}1.58 \\
( \pm 1.54)\end{array}$ & $\begin{array}{l}0.908 \\
( \pm 1.38)\end{array}$ & $\begin{array}{l}0.690 \\
( \pm 0.790)\end{array}$ & $\begin{array}{l}0.532 \\
( \pm 0.964)\end{array}$ & $\begin{array}{l}29.7 \\
( \pm 21.2)\end{array}$ & $\begin{array}{l}395 \\
( \pm 218)^{*}\end{array}$ & $\begin{array}{l}47.4 \\
( \pm 76.0)\end{array}$ \\
\hline & & $\begin{array}{l}\text { ERR } \\
(n=3)\end{array}$ & $\begin{array}{l}7.01 \\
( \pm 1.77)\end{array}$ & $\begin{array}{l}4.50 \\
( \pm 2.23)\end{array}$ & $\begin{array}{l}3.54 \\
( \pm 0.579)\end{array}$ & $\begin{array}{l}0.890 \\
( \pm 0.788)\end{array}$ & $\begin{array}{l}0.400 \\
( \pm 0.693)\end{array}$ & $\begin{array}{l}0.403 \\
( \pm 0.699)\end{array}$ & $\begin{array}{l}0.00 \\
( \pm 0)\end{array}$ & $\begin{array}{l}54.5 \\
( \pm 43.1)\end{array}$ & $\begin{array}{l}576 \\
( \pm 135)\end{array}$ & $\begin{array}{l}15.6 \\
( \pm 10.7)\end{array}$ \\
\hline & & $\begin{array}{l}\text { IRR } \\
(n=3)\end{array}$ & $\begin{array}{l}2.68 \\
( \pm 2.10)\end{array}$ & $\begin{array}{l}2.40 \\
( \pm 0.863)\end{array}$ & $\begin{array}{l}3.77 \\
( \pm 1.50)\end{array}$ & $\begin{array}{l}0.937 \\
( \pm 0.907)\end{array}$ & $\begin{array}{l}0.333 \\
( \pm 0.577)\end{array}$ & $\begin{array}{l}0.200 \\
( \pm 0.346)\end{array}$ & $\begin{array}{l}1.34 \\
( \pm 0.813)\end{array}$ & $\begin{array}{l}17.3 \\
( \pm 16.0)\end{array}$ & $\begin{array}{l}689 \\
( \pm 478)\end{array}$ & $\begin{array}{l}97.4 \\
( \pm 97.0)\end{array}$ \\
\hline & & $\begin{array}{l}\text { All } \\
\text { female } \\
\text { cases }(n=17)\end{array}$ & $\begin{array}{l}4.80 \\
( \pm 2.28)\end{array}$ & $\begin{array}{l}2.86 \\
( \pm 1.44)\end{array}$ & $\begin{array}{l}3.50 \\
( \pm 1.69)\end{array}$ & $\begin{array}{l}1.34 \\
( \pm 1.33)\end{array}$ & $\begin{array}{l}0.72 \\
( \pm 1.17)\end{array}$ & $\begin{array}{l}0.55 \\
( \pm 0.71)\end{array}$ & $\begin{array}{l}0.58 \\
( \pm 0.91)\end{array}$ & $\begin{array}{l}31.87 \\
( \pm 26.12)\end{array}$ & $\begin{array}{l}478.66 \\
( \pm 274.59) * *\end{array}$ & $\begin{array}{l}50.59 \\
( \pm 73.82)\end{array}$ \\
\hline
\end{tabular}

* Statistically significant difference between male and female according to total tooth volume in ECRs ( $p<0.05)$.

** Statistically significant difference between male and female according to total tooth volume in total cases ( $p<0.05)$.

ECR: external cervical resorption; ERR: external replacement resorption; IRR: internal root resorption;

SD: standard deviation; mm: milimeter; $\mathrm{mm}^{3:}$ cubicmilimeter.

Percentages of Axial Classification, Height, and ECR Distribution According to Patel et al.'s Classification

Figure 6 shows the percentages of ECR, ERR, and IRR according to the eight regional axial classification.
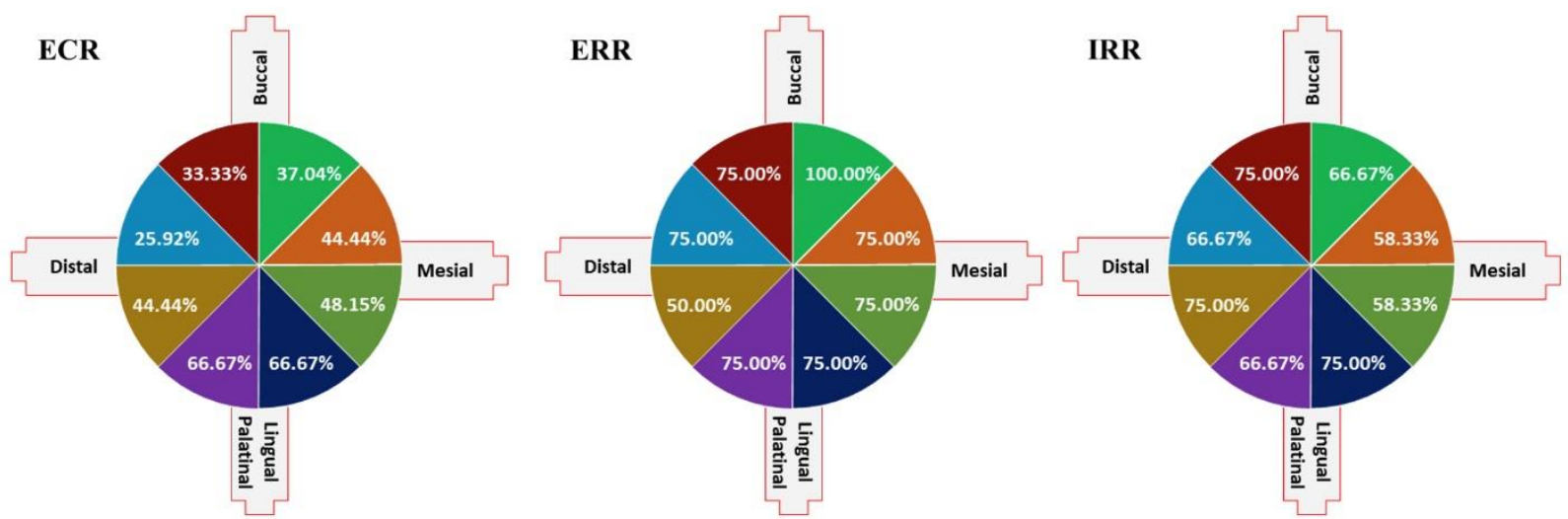

Figure 6. Percentages of ECR, ERR, and IRR according to the eight regional locations in the axial section. ECR: external cervical resorption; ERR: external replacement resorption; IRR: internal root resorption.

ECR was found more in the lingual location than in the other areas $(66.67 \%$ for 4 and 5 regional settlements); ERR and IRR had similar distribution in all locations. The height percentages of ECR, ERR, and IRR in coronal and sagittal sections by region are shown in Figure 7.

\begin{tabular}{|c|c|c|c|}
\hline & ECR & ERR & IRR \\
\hline 1 & $18.5 \%$ & $0 \%$ & $0 \%$ \\
\hline 2 & $40.7 \%$ & $75 \%$ & $50 \%$ \\
\hline 3 & $40.7 \%$ & $75 \%$ & $66,67 \%$ \\
\hline 4 & $0 \%$ & $25 \%$ & $25 \%$ \\
\hline
\end{tabular}

Figure 7. Percentages of ECR, ERR, and IRR according to the height classification. ECR: external cervical resorption; ERR: external replacement resorption; IRR: internal root resorption.
ECR cases resulted in A: $40.7 \%, \mathrm{~B}: 40.7 \%$, C: $3.7 \%$, and D: $14.8 \%$ according to circumferential spread, and also affected the pulp by $88.9 \%$ and the dentin by $11.1 \%$.

\section{Linear/Volumetric Analysis and Age}

According to age distribution, the widest length (corono-apical/mesio-distal/bucco-lingual), the amount of thinnest (buccal/mesial/distal/lingual/ palatinal) dentin thickness and volumetric values (the volume of resorption, the total volume of tooth, and the total/resorption volume ratio) are shown in Figures 8, 9, 10, respectively. In ECRs, IRRs and total cases, the widest lengths decreased with increasing age (Figure 8). 

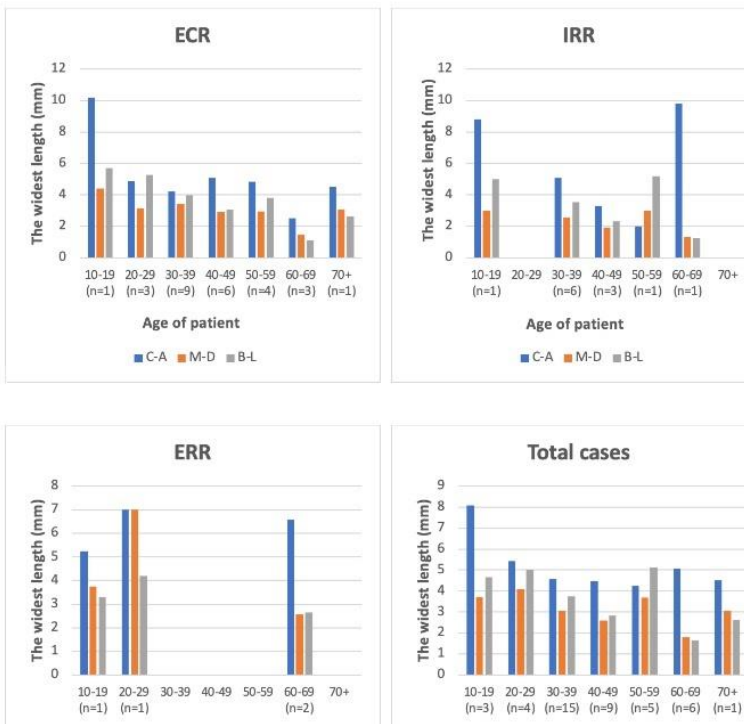

Age of patient

$\| C-A \equiv M-D=B-L$

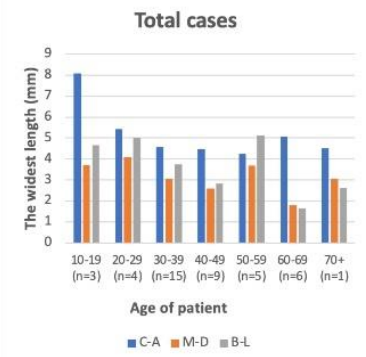

Figure 8. A column charts show the widest length (corono-apical, mesio-distal, bucco-lingual) of ECR, IRR, ERR, and total cases according to age of patients. ECR: external cervical resorption; ERR: external replacement resorption; IRR: internal root resorption; C-A: corono-apical; M-D: mesio-distal; B-L: bucco-lingual.

Of these, only the bucco-lingual length in ECR and total cases, and mesio-distal length in total cases were significant $(\mathrm{p}<0.05)$. In ECRs, IRRs and total cases, the amount of thinnest mesial dentin decreased, whereas the thickness in buccal direction increased (Figure 9).
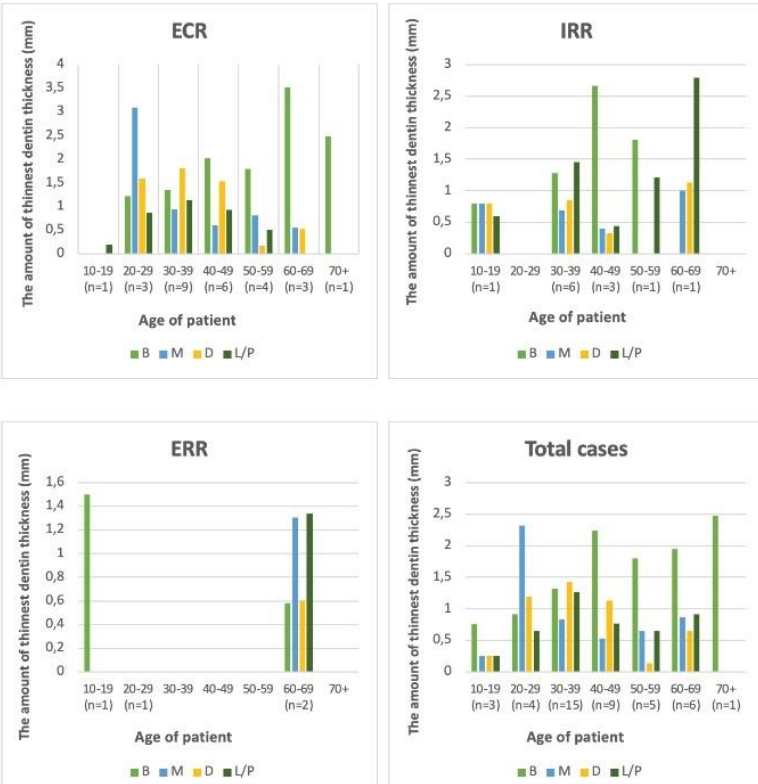

Figure 9. A column charts show the amount of thinnest dentin thickness (buccal, mesial, distal and lingual/palatinal) of ECR, IRR, ERR, and total cases according to age of patients. ECR: external cervical resorption; ERR: external replacement resorption; IRR: internal root resorption; B: buccal; M: mesial; D: distal; L/P: lingual/palatinal.
Of these, only the amount of buccal dentin in ECR and total cases was significant $(\mathrm{p}<0.05)$. Additionally, all volumetric values decreased in ECRs. Of these, only the total tooth volume was significant $(\mathrm{p}<0.05)$ (Figure 10).
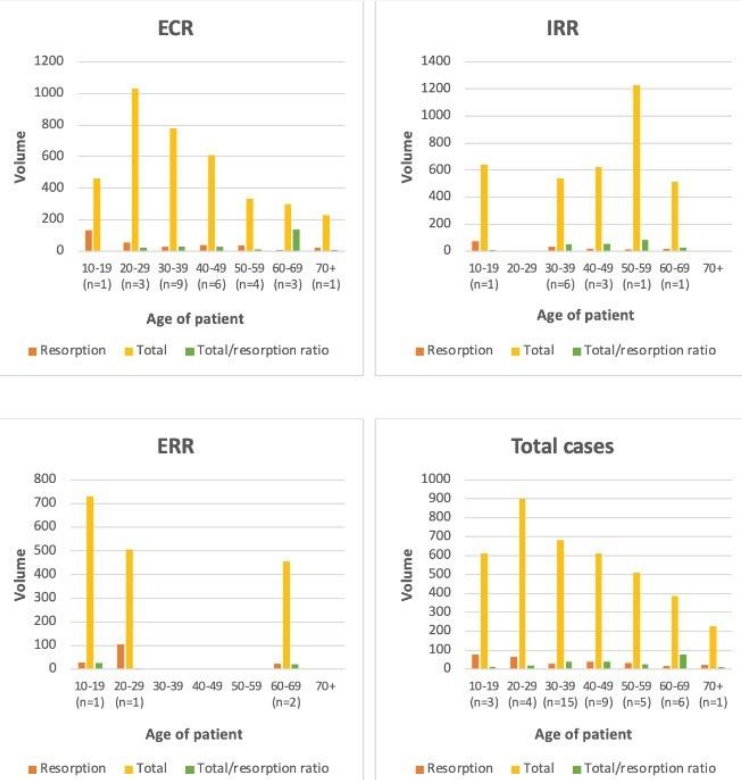

Figure 10. A column charts show the volumetric values (volume of resorption, total volume of tooth and the total/resorption volume ratio) of ECR, IRR, ERR, and total cases according to age of patients. ECR: external cervical resorption; ERR: external replacement resorption; IRR: internal root resorption.

In IRRs, the resorption volume decreased, the total volume and the total/resorption volume ratio increased ( $p>0.05)$. The total volume and the resorption volume significantly decreased in total cases $(\mathrm{p}<0.05)$. Nevertheless, the total/resorption volume ratio increased $(\mathrm{p}>0.05)$. Due to the small sample size of ERR in the study, the age distribution according to these parameters could not be evaluated.

\section{DISCUSSION}

Radiography is a main component in the successful diagnosis of root resorptions as in other endodontic diseases. Nevertheless, conventional methods such as PA and panoramic radiographs can make difficult the interpretation of images as they provide two-dimensional images of 3D structures. By providing 3D images, CBCT can overcome many of the limitations of other radiographic methods. According to the European Society of Endodontology (ESE) position statement, also the American Association of Endodontists (AAE) and American Academy of Oral \& Maxillofacial Radiology (AAOMR) joint 
position statement, CBCT imaging has been recommended for the localization and differentiation of root resorptions, and the determining appropriate management and prognosis. ${ }^{16,17}$ In this study, the 3D volumetric and linear measurements of ECRs, ERRs, and IRRs were assessed using CBCT imaging to understand their nature and differentiation. In addition, the axial classification that would allow an objective interpretation of the diagnosis among clinicians was presented.

ECR occurs in three phases: an initiation phase, an active resorption phase, and a reparative phase, which initially expands coronally and later apically.,18 These directions depend on the movement of clastic cells, which have a relation to inflammatory mediators (e.g. cytokines), hormones (e.g. parathyroid hormone, calcitonin, calcitriol) and growth factors. ${ }^{19,20}$ In the treatment of this resorbed lesion, methods such as the external repair of the resorptive defect with or without endodontic treatment, internal repair and root canal treatment, intentional replantation, periodic review and extraction in untreatable teeth can be applied. ${ }^{21}$ The treatment plan of ECR is dependent on the dimension, localization, and proximity of the lesion to the root canal. ${ }^{22}$ In terms of the resorption dimension, the findings in the present study showed that the widest lengths in ECR was similarly expanding in all three directions. This information is important for the clinicians to consider possible resorbed tissue in all directions while cleaning the resorbed tissue. Although gender seemed to have no effect on the widest lengths, increased age showed a decrease in ECR dimensions, especially bucco-lingual length. The age findings in the widest lengths may indicate that lesions have passed to the reparative phase.

One of the important parameters in the choice of treatment approach is the dentin thickness around the resorbed lesion. Goodell et al. ${ }^{13}$ suggested the Rohde classification in ECRs, which detects the amount of dentin loss in the cervical area. By contrast, the present study compared the amount of thinnest dentin around the resorbed lesion between the axial directions (buccal, mesial, distal, lingual/palatinal). The findings in the present study showed that resorption did not make any difference in the direction of the dentin thickness in ECRs. Interestingly, with increasing age, the amount of the thinnest dentin in the buccal direction increased $(\mathrm{p}<0.05)$. Our findings indicated that the ECRs, which generally progress asymptomatically, may complicate clinical diagnosis by decreasing the pink spot image due to the increase in the thickness of dentin in buccal direction.

The pulp is not usually perforated because of the presence of a pericanalar resorption resistant sheet (PRRS) that protects against pulp penetration. ${ }^{5}$ Nevertheless, in advanced resorption lesions, the root canal may be perforated. ${ }^{18}$ ECR cases affected the pulp at rate of $88.9 \%$ in this study. The detection of PRRS, which have thicknesses of 70 to $490 \mu \mathrm{m}$, with CBCT may interfere with assessment of both the thickness and density of the area. ${ }^{20}$ Also, most of the ECR lesions had less than $180^{\circ}$ of circumferential spread. Although there seems to be no relationship between circumferential spread and pulpal perforation, further investigation is required.

Similar to other studies, ECR was not associated with patient's gender and had a wide age distribution. ${ }^{11,23}$ ECR was most detected in maxillary central incisors (37\%), followed by mandibular central incisors $(18.5 \%)$ and mandibular first molars (18.5\%). Patel et al. ${ }^{22}$ determined the most commonly affected teeth as maxillary central incisors $(30.4 \%)$, followed by mandibular first molars (15.7\%), and mandibular central incisors $(11.3 \%)$. The cause of percentage differences may be that the etiologic factors of ECR differ according to the population investigated.

In contrast to external resorption, IRR occurs inside the pulp canal. For the initiation of IRR, the odontoblast layer and predentin, which is the outer protective of the canal wall, must be damaged. However, without bacterial stimulation, IRR will be self-limiting and does not progress. ${ }^{2}$ It is important to treat the tooth with conservative methods before the IRR advances and consequently compromises the restorability of tooth. If the 
resorbed lesion is limited to the root canal, root canal treatment is the first option. 2 When the the perforation of root walls occurs, the management of the resorbed lesion could be more challenging with treatment methods such as sealing the resorbed area with bioactive cements, and/or surgical approaches. ${ }^{24}$ According to the findings in IRR lesions of this study, the physician should be careful in whole direction during the preparation, irrigation or filling procedures, since there was a possibility similar to the widest lengths and the amount of thinnest dentin of IRR in all directions. Also, as the age increased, the widest lengths of the resorbed lesions may have been reduced in 3D images due to low-grade inflammation of the pulpal tissue.

In the present study, although IRR was more common in maxillary teeth, the distribution of teeth showed homogeneity. Trauma and then pulpal inflammation are the major contributing factors at the beginning of IRR. ${ }^{2}$ The higher percentage of males $(9 / 12,75 \%)$ may be due to more traumatic injuries than in females. Also, IRR classifications using CBCT may be required for the physician to make a correct treatment plan, as with ECR. ${ }^{12}$ This study may guide IRR classifications using CBCT.

ERR occurs as a result of acute damage to periodontal ligament cells due to severe traumatic injuries, such as intrusive luxation or avulsion with extended dry time. ${ }^{25}$ These resorbed lesions cannot be arrested or the process reversed. For this reason, timing of decoronation should be planned according to the age and growth pattern of the patient. ${ }^{26}$ The volumetric analysis of ERR, which was also considered for the first time in this study, may be an important criterion in the tooth decoronation decision. However, the small sample size in this study precluded definitive conclusions from being drawn on the prevalence of ERR. ERR was frequently seen in maxillary teeth $(4 / 4,100 \%)$ because it was generally traumatized and replanted for aesthetics and alveolar bone development.

The change of resorption volume compared with the total volume is the most important factor in the long-term prognosis of resorption. To our knowledge, only Matny et al. ${ }^{14}$ investigated a volumetric quantitative assessment of ECRs. However, this is the first study to compare ECR, ERR, and IRR through volumetric assessment and to examine the age and gender distribution of these resorptions according to this parameter. In ECR lesions, the total volume for males was significantly higher than for females. This might be due to the fact that teeth with greater volume (e.g. premolar, molar) have a greater distribution in males. Interestingly, despite this difference in total tooth volume, no significant difference in resorption volumes of males and females in ECR lesions can lead us to conclude that male's teeth with ECR may be more resistant to fracture. With increasing age, the total tooth volume may have decreased as the ECR may have affected smaller volume teeth. With respect to this result, although the distribution passed to smaller volume teeth as age increases, the resorption volume did not decrease significantly, which may show that the total volume of the tooth in ECR is not a factor in the progression of resorption.

There was no difference between ECR, ERR, and IRR in terms of volumetric values of resorption. This means that even if the resorption classifications and localizations are different, ECR, ERR, and IRR may have close volumetric values due to having similar nature. When total cases were evaluated together, the high total tooth volume in males may be due to the fact that the teeth with greater volume such as molar teeth were more affected by resorption in male. With increasing age, the 3D volume of resorption decreased, suggesting that resorption treatments in adult patients may be more conservative. Also, the slowing of the inflammatory mechanism with age and the increasing secondary dentin thickness throughout life may indicate that resorption progress more slowly. ${ }^{27}$

The apical extent of resorption affects a physician's decision in terms of treatment approach. ECR usually occurs in the cervical region of the tooth and expands in all directions away from portal of entry. ${ }^{20}$ IRR initiates within the pulp space, whereas ERR is a pathologic loss of cementum, dentin, and periodontal ligament 
with subsequent replacement of such structures by bone. ${ }^{28}$ In the height classification, the height values of ECRs were evaluated by including the cervical region according to Patel et al.' ${ }^{12}$ classification. Thus, the total values complemented $100 \%$. In ERRs and IRRs, the total values exceed $100 \%$ since the lesions do not have a specific starting point, such as the entry point of $\mathrm{ECR}$, and are likely to be found simultaneously in the coronal, middle, and apical thirds.

Contrary to previous classifications, in the present study, we added eight settlement classification in axial section, which showed the widest resorption area of the tooth (Figure 4). This classification is of great importance when making treatment decisions and communicating more effective and accurate transmission of lesions among colleagues. Surgical approaches to resorption in the proximal location are more complicated than those found in buccal or lingual areas. For this reason, percentages of availability by regional settlement were determined, and ECR was found more in the lingual region than in other locations (Figure 6). This might be due to more plaque remaining in the lingual direction of the teeth during oral hygiene. The total percentage was not $100 \%$ in total cases because the resorptions were not just located in one region.

The primary limitations of this study were the lack of demografic data of the patients, not evaluating the etiology of resorptions or not selection of the treatment plan according to the parameters evaluated, and the absence of ECR's entry portal. Another limitation was that endodontically treated teeth, which do not have pulp and PRRS, were excluded. ${ }^{29}$ Further research is needed for the volumetric/linear assessment of endodontically treated teeth.

\section{CONCLUSIONS}

Within the limitations of this study, even though the resorption types were different, there was no difference in terms of volumetric and linear analysis in 3D images. ECRs were mostly found in the lingual region, while IRRs and ERRs did not show regional differences in axial sections. There was no difference between genders in terms of volumetric and linear measurements in ECRs and IRRs, except total tooth volume was higher in males in ECRs. With increasing age in ECRs, the buccal dentin thickness increased, and buccolingual length and total tooth volume decreased. Using CBCT imaging, the volumetric/linear analysis and axial classification of resorptions, and demographic differences according to these parameters can help clinicians in deciding the treatment plan and in understanding the resorption nature. Further high-quality studies with larger samples are required to assess the nature and dimensions of root resorptions.

\section{ACKNOWLEDGMENTS}

We would like to acknowledge Dr. Ömer Hatipoğlu for his contributions to statistical analysis.

\section{FUNDING}

No funding agent.

\section{CONFLICT OF INTEREST}

The authors declare that they have no conflict of interest.

\section{ETHICS APPROVAL}

The study design was approved by the Ethics Committee of the Recep Tayyip Erdoğan University Faculty of Medicine.

Kök Rezorpsiyonlarının Konik Iş̧ılı Bilgisayarlı

Tomografi Kullanılarak Ü̧̧ Boyutlu Hacimsel/Lineer Analizi ve Aksiyel Sinıflandırmast: Retrospektif

Çalışma

$\ddot{O} Z$

Amaç: Bu çallş̧manın amacı, konik ışınlı bilgisayarlı tomografi (KIBT) kullanılarak kök rezorpsiyonlarının hacimsel-lineer analizini araşttrmak ve yeni bir aksiyel sinuflandirma sunmaktır. Gereç ve Yöntemler: Çalışmaya 34 hastanin toplamda 43 kök rezorpsiyonlu dişi (eksternal servikal rezorpsiyon (ESR) $(n=27)$, eksternal replasman rezorpsiyon $(E R R)(n=4)$, internal kök rezorpsiyonu (IKR) $(n=12))$ dahil edildi. Dişlerin KIBT görüntülerinde, hacimsel analiz için toplam diş hacmi ve rezorpsiyon hacimleri, lineer analiz için rezorpsiyonların en genis uzunluklart ve bunların etrafindaki en ince dentin kalınlı̆̆ miktarları ölçüldü ve hacimsel/lineer ölçümler yaş ve cinsiyete göre karşılaş̧tırlld. Ek olarak, aksiyel kesitte sekizli bölgesel siniflama uyguland ve bu bölgeler karşılaştırıldl. Veriler Shapiro-Wilk, Pearson's r., Kruskal-Wallis ve 
Dwass-Steel-Critchlow-Fligner post-hoc testleri kullanılarak değerlendirildi. İstatistiksel analiz için anlamlllik $p=0,05$ olarak belirlendi. Bulgular: ESR, ERR ve IKR'lerin hacimsel ve lineer ölçümleri arasinda anlaml bir fark bulunamadl. ESR bulunan erkek hastaların dişinin toplam hacmi kadınlara göre daha yüksek olması dlşında ( $p<0,05)$, ESR ve IKR'lerin hacimsel ve lineer ölçümlerinde cinsiyetler arasinda fark yoktu. ESR'lerde yaş arttıkça bukkal dentin kalınlığl arttı, bukko-lingual uzunluk ve dişin toplam hacmi azald $(p<0,05)$. Aksiyel siniflandirmada, ESR'ler çoğunlukla lingual bölgede bulunurken, ERR ve IKR'lerde bölgesel farklllik gözlenmedi. Sonuçlar: Kök rezorpsiyonlarl farkl lokalizasyon ve siniflandirmalara sahip olsalar da benzer yapıya sahip olduklarından dolayı hacimsel ve lineer ölçümler açısından farklllık göstermediler. KIBT görüntüleme kullanilarak, rezorpsiyonların hacimsel/lineer analizi, aksiyel sinıflandırması ve bu parametrelere göre demografik farkllliklarl klinisyenlerin rezorpsiyon doğasını anlamalarına ve uygun yönetimi belirlemelerine yardımcı olabilir. Anahtar Kelimeler: Sinıflama, konik ışınlı bilgisayarlı tomografi, endodonti, kök rezorpsiyonu.

\section{REFERENCES}

1. Heithersay GS. Invasive cervical resorption. Endod Topics 2004;7:73-92.

2. Patel S, Ricucci D, Durak C, Tay F. Internal root resorption: A Review. J Endod 2010;36:1107-1121.

3. Patel S, Ford TP. Is the resorption external or internal? Dent Update 2007;34:218-229.

4. Patel S, Dawood A, Wilson R, Horner K, Mannocci F. The detection and management of root resorption lesions using intraoral radiography and cone beam computed tomography - an in vivo investigation. Int Endod J 2009;42:831-838.

5. Mavridou AM, Hauben E, Wevers M, Schepers E, Bergmans L, Lambrechts P. Understanding external cervical resorption in vital teeth. J Endod 2016;42:1737-1751.

6. Alamadi E, Alhazmi H, Hansen K, Lundgren T, Naoumova J. A comparative study of cone beam computed tomography and conventional radiography in diagnosing the extent of root resorptions. Prog Orthod 2017;18:37.

7. Owmann-Moll P, Kurol J. Root resorption after orthodontic treatment in high- and low-risk patients: analysis of allergy as a possible predisposing factor. Eur J Orthodont 2000;22:657-663.

8. Bernardes RA, de Paulo RS, Pereira LO, Duarte MAH, Ordinola-Zapata R, de Azevedo JR. Comparative study of cone beam computed tomography and intraoral periapical radiographs in diagnosis of lingual-simulated external root resorptions. Dent Traumatol 2012;28:268-272.

9. de Azevedo Vaz SL, Vasconcelos TV, Neves FS, de Freitas DQ, Haiter-Neto F. Influence of cone-beam computed tomography enhancement filters on diagnosis of simulated external root resorption. J Endod 2012;38:305-308.

10. Scarfe WC, Farman AG. Cone-beam computed tomography. In: White SC, Pharoah MJ (eds). Oral Radiology Principles and Interpretation. 6th ed. St. Louis: Mosby 2004:225-241.

11. Heithersay GS. Invasive cervical resorption: an analysis of potential predisposing factors. Quintessence Int 1999;30:83-95.

12. Patel S, Foschi F, Mannocci F, Patel K. External cervical resorption: a three-dimensional classification. Int Endod J 2018;51:206-214.

13. Goodell KB, Mines P, Kersten DD. Impact of conebeam computed tomography on treatment planning for external cervical resorption and a novel axial slicebased classification system. J Endod 2018;44:239-244.

14. Matny LE, Ruparel NB, Levin MD, Noujeim M, Diogenes A. A volumetric assessment of external cervical resorption cases and its correlation to classification, treatment planning, and expected prognosis. J Endod 2020;46:1052-1058.

15. Shemesh A, Levin A, Hadad A, Itzhak JB, Solomonov M. CBCT analyses of advanced cervical resorption aid in selection of treatment modalities: a retrospective analysis. Clin Oral Invest 2019;23:16351640.

16. Patel S, Durack C, Abella F, Roig M, Shemesh H, Lambrechts P, Lemberg K. European Society of Endodontology position statement: the use of CBCT in endodontics. Int Endod J 2014;47:502-504.

17. AAE and AAOMR Joint Position Statement: Use of cone-beam computed tomography in endodontics 2015 update. J Endod 2015;41:1393-1396.

18. Heithersay GS. Clinical, radiologic, and histopathologic features of invasive cervical resorption. Quintessence Int 1999;30:27-37. 
19. Lindskog SF, Dreyer CW, Pierce AM, Torabinejad

M, Shabahang S. Osteoclastic activity. In: Andreasen JO, Andreasen FM, Andersson L. Textbook and color atlas of traumatic injuries to the teeth. 4th ed. Oxford, UK: Blackwell Munksgaard 2007:137-171.

20. Patel S, Mavridou AM, Lambrechts P, Saberi N. External cervical resorption-part 1: histopathology, distribution and presentation. Int Endod $\mathbf{J}$ 2018;51:1205-1223.

21. Patel S, Foschi F, Condon R, Pimentel T, Bhuva B. External cervical resorption: part 2 - management. Int Endod J 2018;51:1224-1238.

22. Patel K, Mannocci F, Patel S. The assessment and management of external cervical resorption with periapical radiographs and cone-beam computed tomography: a clinical study. J Endod 2016;42:14351440 .

23. Mavridou AM, Bergmans L, Barendregt D, Lambrechts P. Descriptive analysis of factors associated with external cervical resorption. J Endod 2017;43:1602-1610.
24. Nilsson E, Bonte E, Bayet F, Lasfargues JJ. Management of internal root resorption on permanent teeth. Int J Dent 2013;2013:929486.

25. Fuss Z, Tsesis I, Lin S. Root resorption: diagnosis, classification and treatment choices based on stimulation factors. Dent Traumatol 2003;19:175-182.

26. Malmgren B. Ridge preservation/decoronation. J Endod 2013;39:67-72.

27. Gulsahi A, Kulah CK, Bakirarar B, Gulen O, Kamburoglu K. Age estimation based on pulp/tooth volume ratio measured on cone-beam CT images. Dentomaxillofac Radiol 2018;47:20170239.

28. American Association of Endodontists (AAE) [homepage]. Chicago: Glossary of endodontic terms; 2010 [cited 2020 Jun 10]. Available from: https://www.aae.org/specialty/clinicalresources/glossary-endodontic-terms/

29. Mavridou AM, Hauben E, Wevers M, Schepers E, Bergmans L, Lambrechts P. Understanding external cervical tooth resorption patterns in endodontically treated teeth. Int Endod J 2017;50:1116-1133. 